\title{
Evaluation of finrays as a non-lethal ageing method for protected goliath grouper Epinephelus itajara
}

\author{
Debra J. Murie ${ }^{1, *}$, Daryl C. Parkyn ${ }^{1}$, Christopher C. Koenig ${ }^{2}$, Felicia C. Coleman ${ }^{2}$, \\ Jennifer Schull ${ }^{3}$, Sarah Frias-Torres ${ }^{4}$ \\ ${ }^{1}$ School of Forest Resources and Conservation, Fisheries and Aquatic Sciences, University of Florida, 7922 NW 71 st Street, \\ Gainesville, Florida 32653, USA \\ ${ }^{2}$ Florida State University Coastal and Marine Laboratory, 3618 Coastal Highway, St. Teresa, Florida 32358, USA \\ ${ }^{3}$ NOAA-Fisheries, Southeast Fisheries Science Center, 75 Virginia Beach Drive, Miami, Florida 33149, USA \\ ${ }^{4}$ Ocean Research and Conservation Association, 1420 Seaway Drive, Fort Pierce, Florida 34949 USA
}

\begin{abstract}
Currently, there is a conflict between the need to conserve protected fish species and the need to use lethal methods to collect essential biological data, such as age, to assess their population status and recovery trends. We evaluated the precision and accuracy of a non-lethal ageing method for goliath grouper Epinephelus itajara, listed as critically endangered on the IUCN Red List of Threatened Species. Paired finray and otolith samples $(n=21)$ were collected opportunistically from fish that had died primarily from red tide or hypothermal events in Florida coastal waters. Finray ageing proved relatively precise (coefficient of variation $[\mathrm{CV}]=4.24 \%$ ), although less so than otolith ageing $(\mathrm{CV}=1.45 \%)$. Finray ages agreed with otolith ages the majority of the time $(\mathrm{CV}=$ $3.15 \%$ and concordance correlation coefficient $=0.991$ ) for $E$. itajara from 0 to $18 \mathrm{yr}$ of age. Based on a test of symmetry, finray ageing was also relatively unbiased for fish up to $18 \mathrm{yr}$ of age. Further evaluation of any limitations of the method will depend on obtaining more samples, especially from larger, presumably older, fish. Clearly, the non-lethal finray ageing method can be used as an alternative to using otoliths for goliath grouper at least up to $18 \mathrm{yr}$ of age. Finray ageing could significantly reduce the need to sacrifice protected E. itajara to assess their population recovery.
\end{abstract}

KEY WORDS: Epinephelus itajara $\cdot$ Goliath grouper $\cdot$ Otoliths $\cdot$ Finrays $\cdot$ Non-lethal ageing $\cdot$ Florida

\section{INTRODUCTION}

Many groupers are overexploited in the southeastern US and throughout the Caribbean, and stocks are now heavily regulated or protected. Groupers are particularly susceptible to over-exploitation because of a combination of slow growth, long life span (several decades), large size at sexual maturity, site fidelity, complex reproductive biology, and the formation of spawning aggregations in known geographical locations at specific times of year (Sadovy \& Eklund 1999, Coleman et al. 2000, Morris et al. 2000). Goliath grouper Epinephelus itajara is the largest grouper in the Atlantic Ocean, with adults up to $2.5 \mathrm{~m}$ in length (Heemstra \& Randall 1993) and as old as $37 \mathrm{yr}$ (Bullock et al. 1992). Juveniles ( $\leq 6 \mathrm{yr}$ ) are larger than the adults of most other reef fish species and reach $1.2 \mathrm{~m}$ in length (Sadovy \& Eklund 1999, Koenig et al. 2007). Similar to other grouper species, E. itajara displays an ontogenetic habitat shift: juveniles are found almost exclusively in red mangrove Rhizophora mangle habitat (Frias-Torres 2006, Koenig et al. 2007) whereas adults occur offshore on shallow water reefs, ledges, and artificial structures (Sadovy \& Eklund 1999). In 1990, a moratorium on fishing for goliath grouper was initiated in the US due to concerns of its overexploitation (GMFMC 1990, SAFMC 1990). In 1996, the International Union for the Conservation of $\mathrm{Na}$ ture's (IUCN) Red List of Threatened Species listed it as a 'critically endangered species' (Hudson \& Mace 1996). Almost 2 decades after protection in the US, goliath grouper juveniles seem to be returning to 
their original distribution range throughout southwest Florida and the Florida Keys, while the frequency of adult sightings has increased in offshore artificial structures of southwestern Florida (Cass-Calay \& Schmidt 2003, Porch \& Eklund 2003, Frias-Torres 2006, NMFS 2006). This apparent population increase has generated requests by fishermen to re-open the fishery in Florida.

Assessing the population status of both juvenile and adult goliath grouper is critical for addressing these over-exploitation and recovery issues (Kingsley 2004). Obtaining biological data is essential for estimating population parameters (i.e. growth, age-specific reproductive potential, recruitment, and mortality rates; Haddon 2001) that are used as input to stock assessments to predict recovery trajectories. The problem faced by management agencies is how best to obtain the data required for stock assessment without jeopardizing the very population they are trying to protect. The crux of the problem is that most bony fishes are aged by using their sagittal otoliths, which requires killing the fish. Ageing goliath grouper with this method is clearly inconsistent with the goal of conserving the species. Non-lethal ageing methods present a viable alternative, in which dorsal or pectoral finrays can be removed from live fish, which are subsequently released. The advantage of using this method is that older individuals of some species can be aged precisely and accurately (Chilton \& Beamish 1982). In addition, the method can be validated using recaptured oxytetraxcycline-tagged fish, as has been shown for lingcod Ophiodon elongatus (McFarlane \& King 2001).

Finrays have been used to age diverse groups of fishes, including salmonids (Bilton \& Jenkinson 1969, Chilton \& Bilton 1986), hexagrammids (McFarlane \& King 2001), gadoids (Beamish 1981), and sturgeon (Rien \& Beamesderfer 1994). These fish groups are primarily (although not exclusively) from cold-temperate regions where the annuli observed are relatively wide and distinct. Recently, white grunt Haemulon plumieri and gag Mycteroperca microlepis (a grouper) collected from warm-temperate/subtropical waters in Florida have been aged using finrays (Murie \& Parkyn 1999, Debicella 2005). Gag finray ages, in particular, have been successfully compared to otolith ages and have been validated using marginal-increment analysis (Debicella 2005). This suggests that the non-lethal finray ageing method can be used effectively for other warm-temperate/subtropical fish, such as goliath grouper in southwest Florida.

One potential disadvantage of using finrays rather than otoliths is the accumulation of annuli on the edge of the finray in older fish, making it difficult to distinguish and count individual annuli (e.g. lingcod) (Beamish 1981, Cass \& Beamish 1983). The age at which this accumulation occurs is species-specific, however, and may not occur within the range of age determination required for management. For example, lingcod can be aged up to 20 yr before the accumulation of annuli on the edge interferes with accurate age estimates. This is not considered a limitation for stock assessment purposes, however, because there are very few lingcod $>10$ yr taken in the fishery (McFarlane \& Leaman 1993). This is an important consideration for goliath grouper because, although it is long-lived, the majority ( 90\%) of fish in Bullock et al.'s (1992) study were $<24 \mathrm{yr}$ old. It is therefore necessary to compare paired finray and otolith ages over the complete age range of goliath grouper to allow indirect validation of the finray ageing method, based on the assumption that otolith ages provide the most accurate age estimates. This comparative approach also permits determination of the age where compaction of annuli on the edge of the finray may lead to underestimation of the age of the fish.

In the present study, we demonstrate that ageing of goliath grouper can be done using a non-lethal method. By application, age-specific parameters that are key requirements for age-structured stock assessments, such as the age composition of the population, can also be obtained in a non-lethal manner. Our overall goal was therefore to develop and assess the usefulness of non-lethal finray ageing compared to the more common lethal method of ageing using otoliths. To achieve this, our objectives were: (1) to develop ageing criteria for finrays comparable to criteria used for otoliths; (2) to estimate precision of finray ageing compared to otolith ageing; and (3) to estimate accuracy of the finray method.

\section{MATERIALS AND METHODS}

Fish collections. Otolith and finray samples were collected opportunistically from goliath grouper that died as a result of red tides on the west coast of Florida in 2003, 2005 and $2006(n=16)$, illegal capture $(n=1)$, or hypothermal fish kills in southern Florida in January $2008(\mathrm{n}=3)$. One sample was obtained from a fish that died while in captivity in a public aquarium. Date and location of death were recorded whenever possible. For goliath grouper killed during red tides dates are approximate, because the fish were found either floating on the surface of the water or washed up on the beach, most likely $>1 \mathrm{~d}$ post-mortem. Total length of each fish was recorded whenever possible (some fish were too decomposed to obtain accurate measurements). Sagittae were removed, washed, and stored dry. Dorsal finrays were collected by excising them at the insertion point on the back of the fish or as low as 
possible, dried, and stored for later processing. For most fish, rays 2 and 3 were excised because they were the quickest to remove on decomposing fish. For the few intact fish that were available for complete processing $(n=5)$, dorsal finrays 3 through 7 were excised down to the pterygiophores and stored frozen. This latter series of finrays has been shown to be optimal in previous finray ageing studies (Chilton \& Beamish 1982).

Ageing goliath grouper using dorsal finrays. Dorsal finrays were prepared for ageing by using simmering $\left(\sim 95^{\circ} \mathrm{C}\right)$ water to soften attached tissue and then forceps to remove it from the rays. Cleaned finrays were then air-dried, after which they were embedded in epoxy thermoplastic resin (Hysol, Loctite Corporation) and thin-sectioned (varying through 0.7 to $0.9 \mathrm{~mm}$ thickness) using a variable-speed Isomet saw (675 rpm) fitted with a $152.4 \mathrm{~mm}$ diameter blade. Finrays were sectioned from the basal region sequentially up the finrays (distally) until the core of individual finrays was no longer distinguishable (3 to 12 sections, depending on size of the finray). All sections were mounted in sequential order on a glass slide using Flotex (Lerner Laboratories). Finray sections were then examined using a zoom stereomicroscope (20 to $100 \times$ magnification) fitted with a green-filter $(540 \mathrm{~nm}$ narrowband interference filter; Olympus) to enhance contrast between the opaque and translucent zones. Sectioning multiple finrays in sequence had the advantage of providing many views of the finrays, which could be used to clarify the position of the core and first annulus, and the number of both true annuli and 'checks' or false annuli. Checks were identified as multiple narrow, but incomplete, translucent zones that ultimately coalesced into a single larger translucent zone (following Chilton \& Beamish 1982).

One complete annulus in an ageing structure was defined as the combination of one opaque growth zone and one translucent growth zone. Translucent zones are typically counted in finray ageing because they are the narrowest and most distinct zones (Chilton \& Beamish 1982, Murie \& Parkyn 1999, Debicella 2005). However, Debicella (2005) observed that in gag, the translucent zone of finrays was deposited at the opposite time of the year compared to the opaque zone in their otoliths, and that the opaque zone in finrays was deposited in synchrony with the opaque zone in otoliths. The appearance of either a translucent or an opaque zone at the edge of the dorsal finrays was therefore recorded, along with the amount of growth at the edge of the structure. The growth at the edge of the finray was reported as: 0 , zone at edge; 1 , growth $<1 / 3$ of the previously completed increment; 2 , growth $>1 / 3$ and $<2 / 3$ of the previously complete increment; and 3 , growth $>2 / 3$ of the completed increment. After annuli were enumerated and edge codes determined, fish were assigned into an age class based on the number of opaque zones and the amount of translucent growth on the edge of the finray with respect to their collection date, time of opaque zone deposition, and a 1 September birth date following Bullock et al. (1992) (Debicella 2005). Finrays were aged without knowledge of size of the fish or date of capture.

As with any fish species being aged using a new method, it was necessary to establish that the position of the first annulus in finrays of goliath grouper could be consistently located. To test this, radii from the core to the first and second annuli from a section closest to the base of the finray were measured. For consistency, radii were measured on an axis emanating from the core to the outer edge of the finray adjacent to the inner groove of the finray (Fig. 1A) using digital calipers and an image processing system (Motic ${ }^{\circledR}$, version 1.3). Radii for the first and second annuli were then plotted as a function of age class to determine if
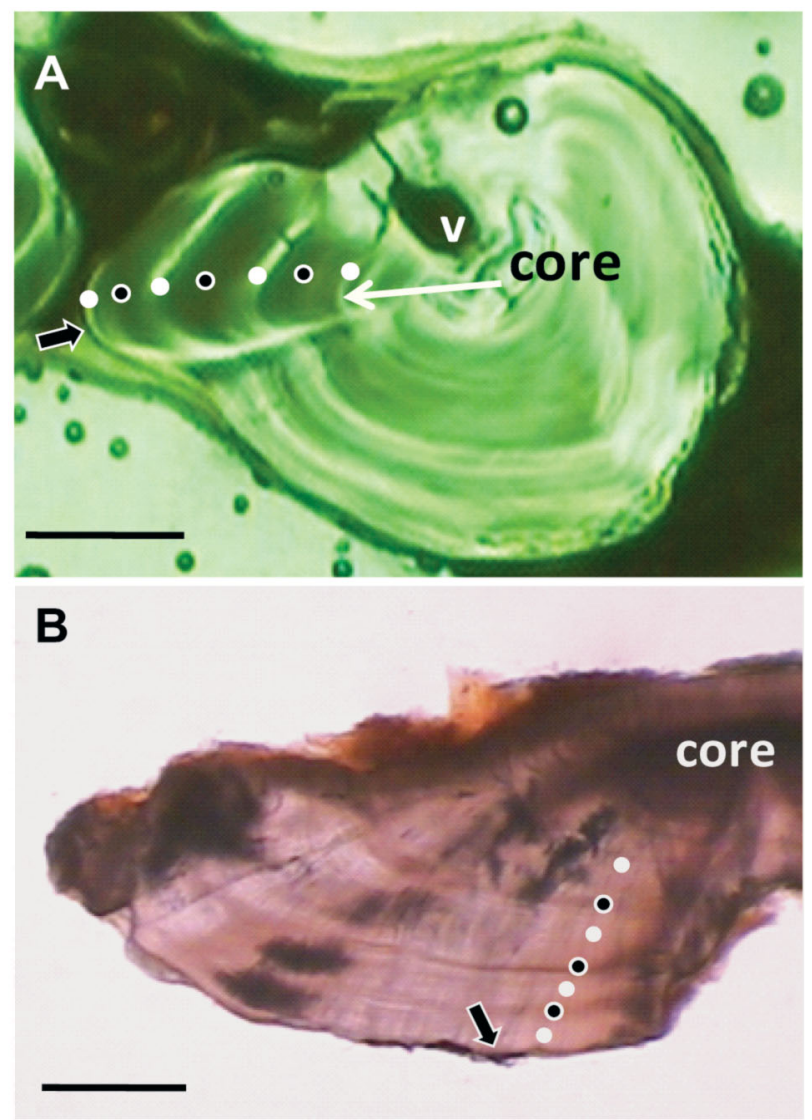

Fig. 1. Epinephelus itajara. Cross-section of (A) a dorsal finray and (B) an otolith from a $4 \mathrm{yr}$ old goliath grouper showing opaque $(\bullet)$ and translucent $(\mathrm{O})$ zones. Black arrows indicate the start of a new opaque zone at the edge of each structure; the white arrow shows the axis used to measure radii to the first and second annuli; 'v': location of vascular tissue. Scale bars $=0.5 \mathrm{~mm}$ 
any overlap in size occurred between the 2 annuli. Overlap in radii, especially with increasing fish age, would indicate that the first annulus may have been missed when ageing those fish (Penha et al. 2004).

Ageing goliath grouper using otoliths. Sagittae of goliath grouper were cross-sectioned through a transverse plane and the core of the otolith using an Isomet variable-speed saw $(350 \mathrm{rpm})$ fitted with a $76.2 \mathrm{~mm}$ diameter diamond-wafering blade. Sections were mounted permanently on slides using Histomount (National Diagnostics) and viewed under transmitted light using a stereomicroscope. Similarly to finray ages, ages from otoliths were assigned based on the number of opaque zones and amount of translucent growth on the edge. Otoliths were aged without knowledge of the size of fish or date of capture.

Comparative age estimates. Otoliths and finrays were read independently by 2 experienced readers (D. J. Murie and D. C. Parkyn), with no knowledge of any previous age estimates, size of fish, or date of capture. Because the sample size was small, finrays were aged prior to establishing otolith ages to avoid reader bias in ageing older fish, in particular. Between-reader precision was estimated for each ageing structure to assess any differences in level of difficulty and consistency in reading structures. Precision between finray and otolith ages was estimated by comparing ages from different structures for individual fish (agreement or disagreement) based on ages estimated by the most experienced finray reader (D. J. Murie) and then calculating the percent agreement among the pairs of ages for all fish combined. Percent agreement by itself is useful when comparing readers or methods over similar age ranges, but it is not age-independent. To estimate precision over the range of ages observed, the coefficient of variation (CV) (Kimura \& Lyons 1991) and average percent error (APE) (Beamish \& Fournier 1981) were calculated. Lower values for CV and APE represent greater precision (e.g. Kimura \& Lyons 1991). Lin's concordance correlation coefficient $\left(\rho_{c}\right)$ (Lin 1989, 2000) was also used to examine the $1: 1$ agreement between readers (Murie \& Parkyn 2005). The concordance correlation ranges from 0 (no agreement) to 1.0 (perfect agreement) and has been shown to be a more robust measure than the more common coefficient of variation (Lin 1989, 2000).

Accuracy of the finray ageing method was validated by comparing finray ages to those derived from otoliths. This was used as a proxy for validating the finray ageing method (i.e. indirect validation) because otolith ageing for goliath grouper has been previously validated using both recaptured oxytetracyclinetagged individuals and marginal-increment analysis (Bullock et al. 1992, Brusher \& Schull 2009, this Theme Section). This comparison was visualized by plotting the finray age as a function of otolith age for each fish. A line denoting the ideal 1:1 relationship was used for reference (Beamish \& Harvey 1969, Sikstrom 1983). Lin's $\rho_{\mathrm{c}}$ (Lin 1989, 2000) was used to examine the 1:1 agreement between the 2 ageing methods. Unlike simple correlation that examines the relationship between $x$ and $y$ regardless of it being 1:1, Lin's concordance correlation simultaneously estimated precision and accuracy of the finray ageing method relative to the otolith ageing method. In addition, a test of symmetry (Hoenig et al. 1995) was used to examine if, and specifically at what age, any ageing biases were evident between otolith and finray ages.

Following ageing comparisons, sizes of goliath groupers as a function of their observed otolith and finray ages were overlain on the von Bertalanffy growth curve of Bullock et al. (1992). This was done to provide a qualitative comparison of size at age based on the 2 ageing structures, as well as based on size at age for fish sampled in 1977 to 1990 (Bullock et al. 1992) versus the present study (2003 to 2008).

\section{RESULTS}

Opportunistic sampling of goliath grouper resulted in a total of 21 paired samples of otoliths and dorsal finrays. Fish ranged in size from 32 to $207 \mathrm{~cm}$ total length, with the majority between 60 and $170 \mathrm{~cm}$; 3 fish were not measured due to decomposition.

Goliath grouper aged using dorsal finrays ranged from 0 to $17 \mathrm{yr}$ of age. Dorsal finrays exhibited a pattern of alternating opaque and translucent zones (Figs. 1A \& 2A). Finray cores were clearly demarcated in basal finray sections from younger fish (Fig. 1A) but were sometimes partially buried in vascular tissue in older fish. In general, however, vascular features in finrays were offset from the core and towards the inner groove of the finray element (Fig. 1A). Translucent zones were narrower than opaque zones in younger fish (Fig. 1A) but as fish aged, the translucent and opaque zones became similar in width (Fig. 2A). Annuli started to compact on the edge of the finray at around 9 to $10 \mathrm{yr}$ of age, although individual annuli were still distinguishable. In older fish, this compaction gave the appearance of a visibly wide area of translucency (Fig. 2A). At increased magnification (up to $100 \times)$, however, the annuli in the compaction zone became evident (Fig. 2A inset).

Two additional difficulties were encountered when ageing goliath grouper using dorsal finrays. First, false annuli or 'checks' were present in some finray sections. Finrays with multiple checks took longer to read because multiple sections needed to be viewed to trace whether the checks actually merged into a translucent 

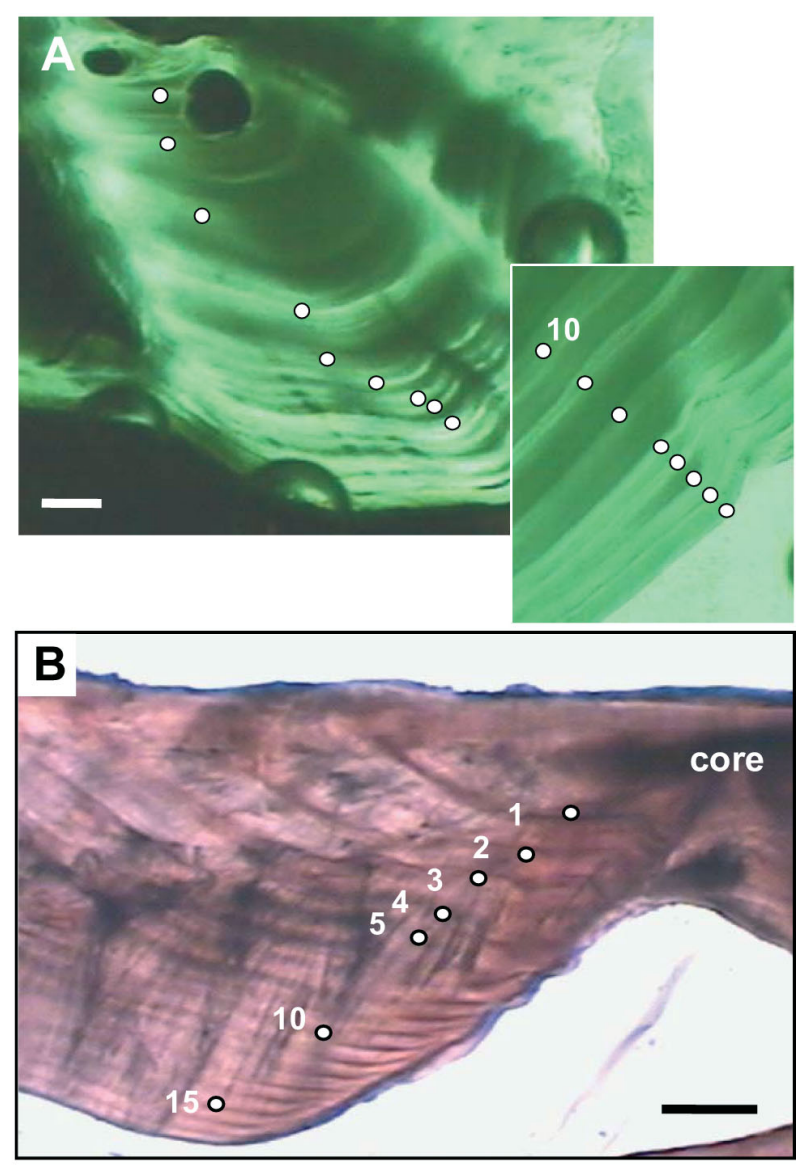

Fig. 2. Epinephelus itajara. Cross-section of (A) a dorsal finray from a goliath grouper aged as a $17 \mathrm{yr}$ old. The finray shows an oblique view of the first 9 translucent zones followed by a wide area of translucency where the annuli are compacted. The inset shows an enlargement of the translucent area with the tenth annulus marked, followed by an additional 7 annuli; and (B) an otolith from the same fish that shows 18 distinct opaque zones. Scale bars $=0.5 \mathrm{~mm}$

zone. Failing to identify checks correctly could have resulted in over-ageing of fish. Second, some finrays had been excised relatively high above their bases, potentially resulting in age underestimation through the loss of early annuli. Whereas all annuli were clearly visible in finrays sampled very close to their base, the first annulus was not always readily apparent in more distal sections. Preliminary examination of radii of the first and second annuli in dorsal finrays, however, indicated no overlap with increasing fish age (Fig. 3). This indicated that the position of the first annulus had been consistently located during ageing, even in older fish.

Goliath grouper aged using otoliths ranged from 0 to 18 yr of age. Sectioned sagittae showed a clear pattern of alternating opaque and translucent growth zones, with a distinct opaque core or focus (Fig. 1B). Annuli in otoliths of older fish (Fig. 2B), although narrower

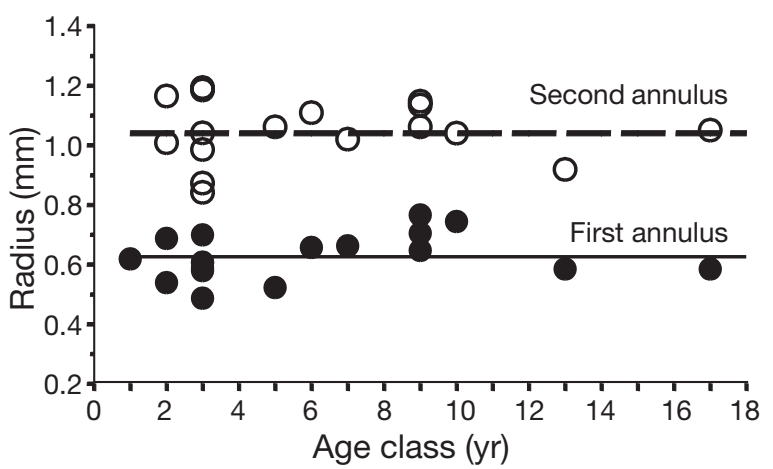

Fig. 3. Epinephelus itajara. Radii of the first and second annuli in finrays as a function of fish age. Horizontal lines represent the median measurement for each annulus

towards the outer edge of the section, were easily distinguished as individual annuli.

Edge analysis revealed that $79 \%$ of the otoliths and finrays had identical edge codes when scored for the amount of translucent zone at the edge of the structure. Fish were not collected throughout the year, so a complete (monthly) edge analysis was not possible. Most fish were collected in March and April ( $\mathrm{n}=13$ ), however, and both the otoliths and the finrays from these fish had a large amount of translucent growth at their edge.

Between-reader precision in ageing goliath grouper using dorsal finrays over 0 to 17 yr was $67 \%$ agreement with no age difference, $89 \%$ agreement within $\pm 1 \mathrm{yr}$, and $100 \%$ agreement within $\pm 2 \mathrm{yr}(\mathrm{n}=21)$. Precision based on APE and CV was 3.00 and $4.24 \%$, respectively. Lin's $\rho_{\mathrm{C}}(0.9788)$ indicated significant agreement in age assignment between readers ( $p=0.023$ ).

Precision was high between 2 independent readers ageing goliath grouper otoliths. Agreement overall was $83 \%$, with $100 \%$ of otolith ages in agreement within $\pm 1 \mathrm{yr}(\mathrm{n}=21)$. Over the observed age range of 0 to $18 \mathrm{yr}$, both APE and CV were low (1.02 and 1.45\%, respectively). In addition, Lin's $\rho_{\mathrm{c}}$ was high $(0.997)$ and indicated near perfect agreement between the 2 readers $(p=0.002)$.

Perfect agreement between otolith ages and finray ages was $71 \%$, with $100 \%$ of the ages agreeing within 1 yr (Fig. 4). Precision estimates between ageing structures were observed to be relatively high, with an APE of $2.22 \%$ and a CV of $3.15 \%$. Lin's $\rho_{c}$ was similarly high (0.991), indicating a significant $(p=0.006) 1: 1$ agreement between ages derived from the 2 methods. This indicated that the finray ageing method was both precise and accurate. Accuracy was based on the assumption that the otolith ageing method, having previously been validated, was providing the most accurate or 'true' ages for fish in this comparison. While it did not appear that fish $\leq 10$ yr of age were being over- 


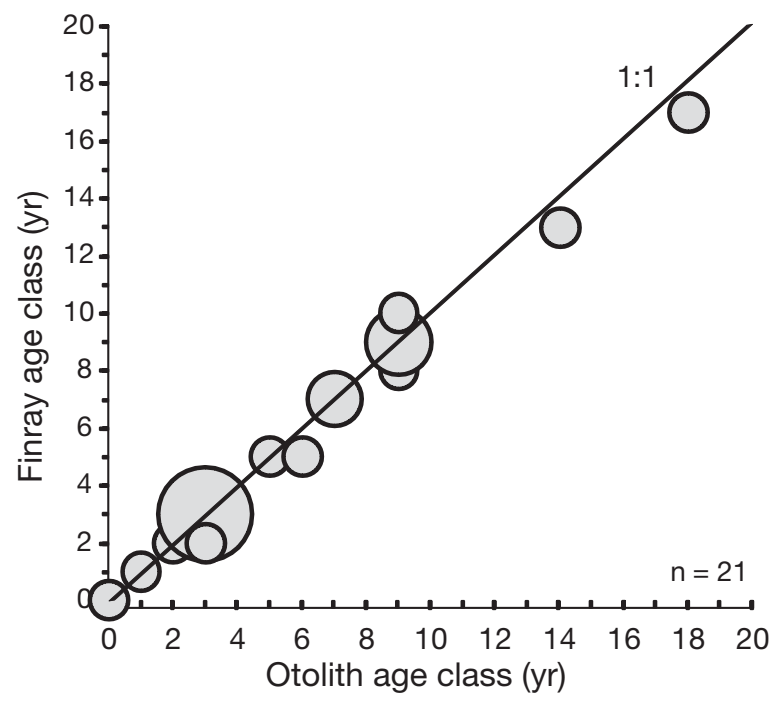

Fig. 4. Epinephelus itajara. Paired comparison of finray ages and otolith ages from the same individual goliath grouper. The line denotes a 1:1 relationship where the finray age is identical to the otolith age. Ages below the line indicate under-ageing using the finray method, and those above the line indicate over-ageing using the finray method

or under-aged, 2 older fish were under-aged by 1 yr (Fig. 4). Hoenig et al.'s (1995) test of symmetry, however, indicated no significant ageing bias using finrays in comparison to otoliths ( $\mathrm{p}=0.54)$.

Qualitatively, size of goliath grouper increased as a function of both observed otolith ages and dorsal finray ages at a similar rate over 0 to 18 yr (Fig. 5). Size at age for goliath grouper sampled in the present study appeared to be modestly greater for fish over 4 yr of age compared to average size at age observed by Bullock et al. (1992).

\section{DISCUSSION}

We have clearly demonstrated that ageing goliath grouper using dorsal finrays is sufficiently precise and accurate to warrant further development as a substitute for lethal methods of age determination. Using finray ageing would garner direct benefits by allowing age-specific biological data to be incorporated into the stock assessment for goliath grouper without compromising management designed to protect the species.

Precision in reading finrays, while lower than that for reading otoliths (CVs of 4.24 and $1.45 \%$, respectively), was within the range of precision for fishes for which ageing is considered to be easy (e.g. Pacific whiting Merluccius productus, $3.2 \%$ ) or of medium difficulty (e.g. walleye pollock Theragra chalcogramma, 5.0\%) (Kimura \& Lyons 1991). In contrast, sablefish Anoplopoma fimbria, which is a species thought to live to

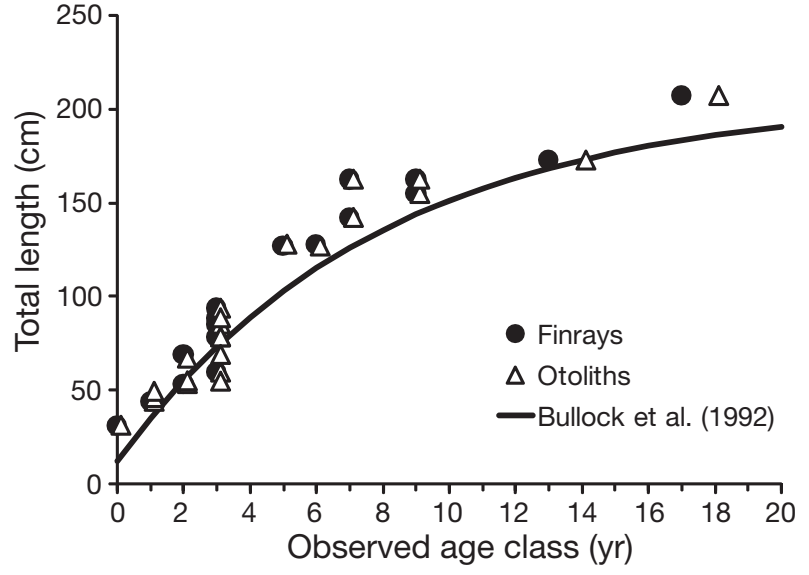

Fig. 5. Epinephelus itajara. Finray and otolith ages superimposed on the von Bertalanffy growth curve modeled by Bullock et al. (1992) for goliath grouper sampled from 1977 to 1990. Ages have been offset from one another for visibility

over $100 \mathrm{yr}$ and considered very difficult to age, has a precision CV of $12.9 \%$, with relatively low agreement between readers (30 to $45 \%$ overall, dropping to $15 \%$ in fish $>7$ yr) (Kimura \& Lyons 1991, Pearson \& Shaw 2004). Despite low precision, age data are used effectively in sablefish stock assessments (Schirripa \& Methot 2001).

Equally important for goliath grouper, the agreement between dorsal finray ages and otolith ages over an age range of 0 to $18 \mathrm{yr}$ was high and unbiased. This is critical, given the concern for under-ageing older fish, which becomes increasingly important to avoid as the goliath grouper population recovers and ages. Deposition of opaque zones in finrays and otoliths coincided, providing further support for our interpretation of these zones representing annuli in finrays. Any ageing disagreements were overall symmetrically distributed. In addition, although compaction of annuli started to be noticeable in goliath grouper around age $9 \mathrm{yr}$, it posed no problem for age determination until ages of 15 to $18 \mathrm{yr}$. In this age range, compaction on the finray edge appeared as a translucent area, alerting the reader to examine the edge more closely. Examining additional paired samples of finrays and otoliths from older goliath grouper is required to determine the age at which the translucent edge of the finrays becomes unreadable.

We suspect that the extant goliath grouper population is somewhat younger than that encountered by Bullock et al. (1992) at a time when exploitation was intense. Of the 382 fish that Bullock et al. (1992) aged, most fish were $<18 \mathrm{yr}$ old, although older fish were sampled ( 16\% between 18 and $25 \mathrm{yr}$, and $~ 6 \%>25 \mathrm{yr}$ old up to a maximum age of $37 \mathrm{yr}$ ). Most goliath grouper in south Florida now are likely $\leq 18$ yr old (i.e. 
consistent with the extent of recovery expected $18 \mathrm{yr}$ post-closure). Application of the non-lethal finray ageing method would therefore be particularly appropriate for continued conservation and management of the species.

Goliath grouper collected in this study were slightly larger at age than fish sampled by Bullock et al. (1992). Although our sample size was limited, it suggests faster growth rates and a density-dependent response to lower population size or increased food availability. One added benefit of using finrays for ageing is that it would allow tracking individual growth rates of recaptured individuals. A more exhaustive study of age and growth is needed to clarify contemporary growth rates and thoroughly evaluate the finray ageing method for older fish.

There has been some debate on the relative merits of using finrays or spines to age protected fish species in a non-lethal manner. Brusher \& Schull (2009) validated the use of the dorsal fin spines to accurately age juvenile goliath grouper $<6$ yr old. After this age, the central lumen of goliath grouper dorsal spines becomes occluded with vascular tissue that prevents accurate age estimation (Brusher \& Schull 2009, D. J. Murie pers. obs.). Spines are formed as a single fused element of bone with a central lumen that may be filled with vascular tissue, or be hollow due to resorption of the spine nucleus (Penha et al. 2004). In contrast, each finray comprises 2 parallel finray elements (lepidotrichia). The vascular tissue of the finray lies between the lepidotrichia and is thus offset from the core of the finray (which itself does not occupy a central position in the finray) in both goliath grouper (present study) and gag (Debicella 2005). Although occlusion or resorption processes can occur in finrays (Chilton \& Beamish 1982, McFarlane \& King 2001) — and we may find in older fish that occlusion becomes more evident-it may have less of an impact on our ability to age samples using finrays than spines.

More significant problems encountered using finrays to age goliath grouper were (1) the ability to collect finrays close to the basal structures of the dorsal fin, and (2) the ability to read the compacted annuli at the edge of the finray. Goliath grouper have flesh and skin that extend part way up the anterior portion of their dorsal and anal fins, making collection of finrays 2 and 3 problematic. Sampling finrays from the posterior region of the dorsal fin, where the thickness and height of overlaying fleshy tissue and skin is at its minimum, would be easier and less intrusive. This is plausible because more posterior dorsal finrays (rays 3 to 7 ) all have clear, distinct annuli, although location-specific precision and accuracy of ageing these finrays needs to be examined. In addition, we need to determine how close to the fin base the finrays need to be removed to capture the first annulus. In gag, sampling finrays at the level of the fleshy back of the fish, rather than at the base of the finrays, resulted in non-biased age estimates (Debicella 2005). Indeed, Koenig et al. (2007) and Brusher \& Schull (2009) sampled dorsal spines and finrays from live, juvenile goliath grouper (<1000 mm total length) with high survival of released fish (up to a $40 \%$ recapture rate), multiple recaptures of individual fish, and evidence of spine and finray regrowth. These studies clearly demonstrate that these ageing structures can be collected in a non-lethal and non-destructive manner. Methods used to sample these large juveniles have also been modified to effectively and humanely sample large, live adults (C. C. Koenig pers. obs.).

An added benefit of obtaining better information about the goliath grouper age distribution, particularly as it relates to the spatial dynamics of that distribution, is determining the extent to which recovery has occurred. It is essential to understand the basis of the reports of apparent increased numbers of goliath grouper in coastal habitats. An increase in the proportion of relatively older individuals in the population is viewed as a signal of recovery compared to the exploited population where the age structure may be skewed towards the relatively younger ages. However, an increase in the proportion of juveniles may represent strong recruitment, but does not necessarily reflect full recovery of the age distribution. This is particularly important for estimating sustainability of the older portion of the spawning population.

Acknowledgements. We are extremely grateful to L. Bullock (Florida Fish and Wildlife Research Institute), V. Koch (University of Miami), and D. DeMaria (Key West, FL) for help with collecting samples from decomposing fish. This study was collectively supported by the Program of Fisheries and Aquatic Sciences, IFAS, University of Florida, Florida State University Coastal and Marine Laboratory, NOAA-Fisheries, Southeast Fisheries Science Center and the Disney Wildlife Conservation Fund.

\section{LITERATURE CITED}

Beamish RJ (1981) Use of fin-ray sections to age walleye pollock, Pacific cod, and albacore, and the importance of this method. Trans Am Fish Soc 110:287-299

Beamish RJ, Fournier DA (1981) A method for comparing the precision of a set of age determinations. Can J Fish Aquat Sci 38:982-983

Beamish RJ, Harvey HH (1969) Age determination in the white sucker. J Fish Res Board Can 26:633-638

Bilton HT, Jenkinson DW (1969) Age determination of sockeye (Oncorhynchus nerka) and chum (O. keta) salmon from examination of pectoral fin rays. J Fish Res Board Can 26:1199-1203

Brusher JH, Schull J (2009) Non-lethal age determination for juvenile goliath grouper Epinephelus itajara from southwest Florida. Endang Species Res 7:205-212 
Bullock LH, Murphy MD, Godcharles MF, Mitchell ME (1992) Age, growth, and reproduction of jewfish Epinephelus itajara in the eastern Gulf of Mexico. Fish Bull 90: 243-249

Cass AJ, Beamish RJ (1983) First evidence of validity of the fin-ray method of age determination for marine fishes. $\mathrm{N}$ Am J Fish Manag 3:182-188

Cass-Calay S, Schmidt TW (2003) Standardized catch rates of juvenile goliath grouper, Epinephelus itajara, from the Everglades National Park creel survey, 1973-1999. Sustainable Fisheries Division Contribution SFD-2003-0016. Southeast Fisheries Science Center, Miami, FL

Chilton DE, Beamish RJ (1982) Age determination methods for fishes studied by the Groundfish Program at the Pacific Biological Station. Can Spec Publ Fish Aquat Sci 60:102

Chilton DE, Bilton HT (1986) New method for ageing Chinook salmon (Oncorhynchus tshawytscha) using dorsal fin rays and evidence of its validity. Can J Fish Aquat Sci 43: $1588-1594$

Coleman FC, Koenig CC, Huntsman GR, Musick JA and others (2000) Long-lived reef fishes: the grouper-snapper complex. Fisheries 25:14-21

Debicella JM (2005) Accuracy and precision of fin-ray aging for gag grouper (Mycteroperca microlepis). Master's thesis, University of Florida, Gainesville, FL

Frias-Torres S (2006) Habitat use of juvenile goliath grouper Epinephelus itajara in the Florida Keys, USA. Endang Species Res 2:1-6

GMFMC (Gulf of Mexico Fishery Management Council) (1990) Amendment number 2 to the fishery management Plan for the reef fish fishery of the Gulf of Mexico. Gulf of Mexico Fishery Management Council, Tampa, FL

Haddon M (2001) Modelling and quantitative methods in fisheries. Chapman \& Hall/CRC Press, New York

Heemstra PC, Randall JE (1993) FAO species catalogue: groupers of the world (family Serranidae, subfamily Epinephelinae). An annotated and illustrated catalogue of the grouper, rockcod, hind, coral grouper and lyretail species known to date. FAO Fisheries Synopsis 16 (125)

Hoenig JM, Morgan MJ, Brown CA (1995) Analysing differences between two age determination methods by test of symmetry. Can J Fish Aquat Sci 52:364-368

Hudson EJ, Mace GM (1996) Marine fish and the IUCN Red List of Threatened Animals. Report of the workshop held in collaboration with the WWF and IUCN at the Zoological Society of London, April 29-May 1, 1996

Kimura DK, Lyons JJ (1991) Between-reader bias and variability in the age-determination process. Fish Bull 89: 53-60

Kingsley MCS (ed) (2004) The goliath grouper in southern Florida: assessment review and advisory report. Report prepared for the South Atlantic Fishery Management Council, the Gulf of Mexico Fishery Management Council, and the National Marine Fisheries Service. Southeast Data and Assessment Review. South Atlantic Fishery Management Council, Charleston, SC

Koenig CC, Coleman FC, Eklund AM, Schull J, Ueland J (2007) Mangroves as essential nursery habitat for goliath grouper, Epinephelus itajara. Bull Mar Sci 80:567-586

Lin LIK (1989) A concordance correlation coefficient to evaluate reproducibility. Biometrics 45:255-268

Editorial responsibility: Kevin Rhodes,

Hilo, Hawaii, USA
Lin LIK (2000) A note on the concordance correlation coefficient. Biometrics 56:324-325

McFarlane GA, King JR (2001) The validity of the fin-ray method of age determination for lingcod (Ophiodon elongatus). Fish Bull 99:459-464

McFarlane GA, Leaman BM (1993) Offshore lingcod. In: Leaman BM, Stocker M (eds) Groundfish stock assessments for the West Coast of Canada in 1992 and recommended yield options for 1993. Can Tech Rep Fish Aquat Sci 1919, Fisheries and Oceans Canada, Nanaimo, BC, p 33-48

> Morris JV, Roberts CM, Hawkins JP (2000) The threatened status of groupers (Epinephelinae). Biodivers Conserv 9: 919-942

Murie DJ, Parkyn DC (1999) Age, growth, and sexual maturity of white grunt in the eastern Gulf of Mexico: Part II. Final Report, Florida Marine Research Institute, St. Petersburg, FL

Murie DJ, Parkyn DC (2005) Age and growth of white grunt (Haemulon plumieri): a comparison of two populations along the Florida west coast. Bull Mar Sci 76:73-93

NMFS (National Marine Fisheries Service) (2006) Status report on the continental United States distinct population segment of the goliath grouper (Epinephelus itajara). January 12, 2006. NMFS, St.Petersburg, FL. http://sero. nmfs.noaa.gov/pr/pdf/Final_Status_Report_on_the_Goliath_ Grouper.pdf

Pearson DE, Shaw FR (2004) Sources of age determination errors for sablefish (Anoplopoma fimbria). Fish Bull 102: 127-141

> Penha JMF, Mateus LAF, Petrere MP Jr (2004) A procedure to improve confidence in identification of the first annulus in fin-spines of fishes. Fish Manag Ecol 11:135-137

Porch CE, Eklund AM (2003) Standardized visual counts of goliath grouper off South Florida and their possible use as indices of abundance. Sustainable Fisheries Division Contribution SFD-2003-0017. Southeast Fisheries Science Center, Miami, FL

> Rien TA, Beamesderfer RC (1994) Accuracy and precision of white sturgeon age estimates from pectoral fin rays. Trans Am Fish Soc 123:255-265

Sadovy Y, Eklund AM (1999) Synopsis of biological data on the Nassau grouper, Epinephelus striatus (Bloch, 1792), and the jewfish, E. itajara (Lichtenstein, 1822). U.S. Dep. Comm., NOAA Tech. Rep. NMFS 146, and FAO Fisheries Synopsis 157

SAFMC (South Atlantic Fishery Management Council) (1990) Amendment 2, Regulatory Impact Review, Initial Regulatory Flexibility Analysis, and Environmental Assessment for the Fishery Management Plan for the Snapper Grouper Fishery of the South Atlantic region, Charleston, SC

Schirripa MJ, Methot RD (2001) Status of the sablefish resource off the U.S. Pacific coast in 2001. In: Pacific Fishery Management Council (ed) Status of the Pacific coast groundfish fishery through 2001 and recommended acceptable biological catches for 2002: Stock assessment and fishery evaluation. Pacific Fishery Management Council, Portland, OR

Sikstrom CB (1983) Otolith, pectoral fin ray, and scale age determinations for arctic grayling. Prog Fish-Cult 45: 220-223

Submitted: February 19, 2008; Accepted: September 17, 2008 Proofs received from author(s): November 2, 2008 